\title{
Bringing Managers Back in: Support for Gender-Equality Measures in the Business Sector ${ }^{1}$
}

\section{Ragni Hege Kitterød ${ }^{2}$}

Research Professor, Institute for Social Research, Norway

\section{Mari Teigen}

Research Professor, Institute for Social Research, Norway

\begin{abstract}
The progression of gender balance in top positions at big corporations in Nordic countries has not lived up to the expectations. Inspired by studies emphasizing the crucial role of top management in gaining support for gender-equality measures to make changes happen, we set out to investigate what kind of policies top managers in Nonway would prioritize to further gender balance in the executive ranks. We found that active recruitment policies receive the strongest support and quota and preferential-treatment policies the least support. We found clear similarities between men and women in the ranking of measures, although women generally indicated stronger support for most measures. We found no differences related to gender composition of the management group, but some differences across company types (subject to CBQ or not) were revealed. Although corporate-board quotas received the least support, there was no indication that these measures were strongly objected.
\end{abstract}

\section{KEYWORDS}

Business / corporate-board quotas / gender-equality measures / top managers

\section{Introduction}

$\mathrm{n}$ Nordic countries, as is the case globally, top management positions in the corporate world are predominantly held by males. In these countries, widely recognized for their gender-equality progress (Lister 2009; Melby et al. 2009; Teigen \& Skjeie 2017), continued male dominance has been characterized as a gender-equality paradox, with family-friendly welfare-state policies, welcoming women into the labor market in great numbers, but not when it comes to reaching the corporate world's executive ranks (Datta Gupta et al. 2008; Hakim 2011; Mandel \& Semyonov 2006; Shalev 2008). In any case, there is little doubt that the progression of gender balance in top positions at big corporations in Nordic countries has not been in line with expectations domestically or globally.

This continued male dominance and lack of will to take action in the business realm to alter male-dominated structures constitute an important context for why the Norwegian government in 2003 adopted gender quotas for corporate boards (CBQs) (Teigen 2015, 2018). CBQs have been effective in furthering gender balance on boards in the

\footnotetext{
${ }^{1}$ You can find this text and its DOI at https://tidsskrift.dk/njwls/index.

${ }^{2}$ Corresponding author: Ragni Hege Kitterød. E-mail: hege.kitterod@samfunnsforskning.no
} 
companies that are part of the regulation, but few signs indicate that any ripple effects were generated from gender-balanced corporate boards to improving gender balance in top management positions. A major reason might be because CBQs were not designed to recruit women into executive ranks. As argued by Dobbin et al. (2015), some policies appear to appeal less to managers than others. For instance, in an American context, Dobbin et al. (2015) find that control-oriented, state-imposed policies, in particular, may have elicited unintended negative effects. If this also applies in a Norwegian context, could CBQ have had a demotivating effect and contributed to the lack of ripple effects from CBQs in Norway?

This article is inspired by a 'call to bring the managers back' into the study of workplace inequality, emphasizing the crucial role of top managers for promoting equality and diversity in the workplace (Castilla 2011; Dobbin et al. 2015). We set out to investigate what kinds of policies top managers in Norway would prioritize to further gender balance in top management. We argue that initiatives have been tried out to further gender balance in top positions, but little is known about what initiatives top managers actually believe in and are engaged by, which assumingly is important for making change happen.

We will examine possible gender differences among top managers in their degree of support for different gender-equality policies, based on the expectation that such differences send a message about what the main obstacles are to advancing gender balance in top positions in the corporate world. Extant literature has shown a growing gender egalitarianism and that women in general support gender-equality policies more fervently than men (Davis \& Greenstein 2009; Inglehart \& Norris 2003; Knight \& Brinton 2017), but less is known about possible gender differences among top managers. A study by Teigen and Wängnerud (2009) indicates that within several sectors in Norway and Sweden, not only are women in top management positions more supportive of gender-equality policies than men, but women business elites are also more moderate in their support than women in other types of elite realms. According to the 'queen bee' theory, women in highly male-dominated sectors may reproduce instead of challenge the gender hierarchy because they adjust to and assimilate into the male culture (Derks et al. 2016). Hence, women who have managed to break through the glass ceiling and become top managers at private-sector companies may not necessarily diverge from their male counterparts in their views on gender-equality policies and initiatives, or at least not all types of initiatives.

Using this backdrop for the present study, we investigate the support from top managers within the biggest corporations in Norway for various initiatives to promote gender balance among top management. On the basis of a survey among top managers at the 200 biggest Norwegian companies by revenue, including both companies that are subject to CBQ regulation and companies that are not, we examine what types of initiatives female and male managers believe in most strongly and which they support the least. We also discuss whether and how top managers' ranking of gender-equality measures, including quota policies, can help in understanding the lack of 'ripple effects' from CBQs.

The paper is guided by four research questions: First, what gender-equality measures are most and least supported by top managers? Second, are female top managers more supportive of gender-equality initiatives than their male colleagues and does their supports vary among different types of initiatives? Third, we explore possible gender 
differences further and ask whether female top managers diverge less from their male counterparts in more-gender-balanced than less-gender-balanced management groups. Fourth, in order to get a better understanding of the relationship between gender-quota regulations on corporate boards and top managers' opinions on measures to further gender balance in top management, we ask whether support for gender-equality measures differ based on whether a company is subject to CBQ regulations or not?

In our examination of top managers' support of different gender-equality measures, we follow Dobbin et al. (2015), and differentiate between measures that approach managers' behavior, such as management training and recruitment, on the one hand, and measures that constrain managers' discretion to discriminate, such as different types of control systems, on the other hand.

The paper is structured as follows. First, we present central aspects of gender-equality policies in Norway as an important context for the study of gender-equality measures to increase gender balance in top management in Norwegian business life. Second, we present literature on conditions for successful implementation of equality policies, as well as literature on gender differences in support of gender-equality measures. Next, we present our data, method, and results of analyses on our four research questions. Finally, we examine our findings in light of the patterns of top managers' support for gender-equality measures and how their priorities can help us understand obstacles to gender-equality advancements. We also reflect on the implications suggested by consistent gender differences in support for gender-equality measures and how our findings relate to Norwegian mandates on gender quotas for corporate boards.

\section{The Nordic gender equality policy context}

The Nordic gender equality model is characterized by policies instituted by the state (Teigen 2018), and to a lesser degree by policies developed by companies and other labor market actors. Generally, Nordic gender-equality policies comprise three pillars: genderequality legislation, gender-quota policies, and family-friendly welfare-state policies.

Norway, as the first among the Nordic countries passed the Gender Equality Act in $1978,{ }^{1}$ which took effect in 1979 . The law was innovative in the sense that it combined prohibition of gender-based discrimination with positive duties and positive differential treatment (affirmative action) to promote gender equality. The explicit provision in favor of positive action was an important reason why gender-equality policies in Norway have emphasized gender quotas and positive-action policies, and why this has been emphasized more in Norway compared with other Nordic countries (Teigen 2012, 2018).

Gender-quota policies were established in Norway to promote and regulate gender parity in decision-making assemblies. Since 1981, the Gender Equality Act stated that both genders should be represented on public committees, and since 1988, the law mandated gender parity, at least $40 \%$ for each gender, on state-appointed commissions, etc. The same regulation was included in the Municipal Act since 1992 for municipal commissions. Most political parties voluntarily have adopted gender-parity policies as well. Since the mid-1970s, five of the major Norwegian political parties adopted such measures. The Conservative Party, Progress Party, and Green Party have no such regulations. Party quotas also imply a 'zipper system', in which candidates of each gender alternate on election lists, as well as demand at least $40 \%$ of each gender on internal 
party bodies. For about 25 years, the only statutory gender-quota procedure in Norway was applied to public committees. In 2003, the Norwegian Parliament adopted gender quotas for corporate boards, including the boards of public limited companies (PLCs), inter-municipal companies, and state-owned companies. Legislated corporate-board quotas were expanded to include cooperative companies and municipal companies in 2008 and 2009, respectively (Teigen 2018). Numerous, but mostly small- and mediumsize private limited companies are not subject to gender-quota laws. Expansion of the scope of the legislation to include these companies, especially the largest of them, has been discussed, but has not been taken up by the right-wing government that came to power in 2013.

Work-family policies in Norway, as in other Nordic countries, are built on the dualworker/dual-career family model (Ellingsæter \& Leira 2006), and they receive massive support among the population (Hellevik \& Hellevik 2012). Key elements in promoting gender equality have been the right to job-protected and generously compensated leave for both parents in connection with child birth, and publicly subsidized, high-quality child care (Ellingsæter \& Leira 2006). Norway was the first country to introduce a quota for fathers in the parental-leave scheme (Brandth \& Kvande 2013). As for daycare, there long had been an unmet demand in Norway, particularly for the youngest children, but today, the vast majority of children below school age attend a kindergarten (Ellingsæter et al. 2017). Although Norwegian work-family policies ease the combination of paid work and childcare for both parents, it is also noticeable that generous family-friendly policies may have counterproductive and unintended consequences for women's power in the labor market, such as the concentration of women in public-sector jobs, high parttime working rates among women, an underrepresentation of women in top positions in industry and commerce, and a persistent gender gap in wages (Datta Gupta et al. 2008; Mandel \& Semyonov 2006). The massive and continued male dominance in top positions in the business sector is a particular visible sign of prevailing unequal gender relations in the Nordic countries, as characterizing all the Nordic countries, with some indications of Denmark lagging behind (Niskanen 2011). Some also argue that the compressed wage structure in Norway, as well as in the Nordic countries, makes it expensive to outsource housework tasks, which would otherwise facilitate long working hours for both partners in a couple (Datta Gupta et al. 2008; Petersen 2002). However, Korpi et al. (2013) disagree with the idea that well-developed work-family policies damage highly educated women's career prospects.

\section{Measured impact and top managers' engagement}

While much research has analyzed the sources of inequality and gender imbalance and the adoption of policies (the politics of policies), fewer studies have been conducted to analyze the implementation and success of policies and programs to counter gender inequalities (Engeli \& Mazur 2018). However, studies of effects from policies and initiatives to promote gender balance and diversity in the workplace are growing in importance, and a main finding is that programs and measures that engage managers are the most successful in terms of integrating equality and diversity (Dobbin et al. 2015).

In a major study of 816 establishments in the US between 1971 and 2002, Dobbin et al. (2015) used panel data to explore the effects of various types of reforms typically 
adopted to promote equality and diversity at the workplace. They distinguish between four groups of measures. The first group comprises those that aim to engage managers. For instance, special recruitment (i.e., affirmative action) and management training have been found to engage managers in recruiting, nominating, and training women and minorities. A second group of measures aims to restrict managers from discriminating through different types of control systems, such as job tests, performance ratings, and grievance systems. The idea is to prevent discriminatory behavior by managers, instead of engaging them. Such measures have elicited opposition among managers, rendering them counterproductive. A third group of measures aim to increase transparency. Jobopening transparency is emphasized, as well as formal, explicit job ladders, to stipulate and define eligibility for jobs and pathways upward. A fourth group of reforms establishes diversity and equality monitoring through the appointment of experts to take charge. The assumption is that monitoring for diversity will force managers to scrutinize themselves for biases, and that evaluation apprehension will reduce rebellion against discretion-control practices.

Because categorizations by Dobbin et al. (2015) are taken from U.S. companies they are not necessarily transferrable to a Norwegian business context, where equality and/or diversity policies at the corporate level are less developed. Moreover, they apply to the effects of different initiatives, not to top managers' support for various tools, which is the topic of our paper, and their study also covers the 1970s, 1980s, and 1990s, whereas we use more recent data (from 2014). Still, we believe that managers' support of different measures along the distinction between, more or less, control-oriented measures and the degree to which they put constraints on managers' discretion may shed light on barriers to change in a Norwegian context as well.

Although the survey used in the present article was not designed to comply with the research by Dobbin et al. (2015), our analysis of the first research question concerning what gender-equality measures are most and least supported by top managers is guided by a distinction between measures that may involve and engage managers on the one hand, and more regulatory-related measures imposed on them on the other hand.

\section{Gender differences, role models, and 'queen bees'}

Cultural attitudes toward gender equality have changed and become more positive globally. Still, women are generally more concerned with gender equality and more supportive of gender-equality policies than men (Davis \& Greenstein 2009; Inglehart \& Norris 2003). Yet, little is known about gender differences in attitudes among men and women who live relatively desegregated, for example, men and women in the highest-ranked, highest-paid, and most-influential corporate positions. However, Norwegian and Swedish leadership studies from the early 2000s indicate significant gender differences in attitudes on gender-equality measures within different elite groups, although women managers in elite business ranks are less supportive than women on elite levels in other sectors (Teigen \& Wängnerud 2009). Nevertheless, these findings indicate that gender inequality is perpetuated by men, and that the presence of more women in top management will make a positive impact on women's career opportunities. Kunze and Miller (2017) find that there is less of a gender gap in promotions at companies where there are more women working as top managers; they concluded that increased gender balance in 
corporate management may have a positive effect on the recruitment of women in lower ranks of the organization. Huffman's (2013) study points in the same direction by providing a strong critique of supply-side explanations on wage inequality and other forms of workplace stratification, with an emphasis on the gendered nature of organizational structures and processes, the important role of managers in general, and the role women managers can play.

The importance of women role models in male-dominated realms has been emphasized with the argument that more women in these realms have an important motivating effect on other women, who then become more motivated to pursue careers in maledominated realms as a consequence of the existence of women role models (Ambrose $\&$ Schminke 2015; Terjesen et al. 2009; Wolbrecht \& Campbell 2007).

However, another camp of literature says women managers in male-dominated organizations may reproduce rather than challenge the gender hierarchy (Derks et al. 2016). The argument is that the few women who have made it to the top may choose to distance themselves from junior women because they may feel a need to reduce their associations with less-successful women in the organization (Kanter 1977). Women not helping women has been called the 'queen bee' phenomenon, understood as a psychological mechanism that Derks et al. (2016) argue is caused by hostility and gender discrimination women often face in male-dominated work settings. Essentially, the few women in male-dominated fields - token women - have a tendency to adjust and assimilate into the male culture and become part of the culture of discrimination against women. The point is not that woman 'queen bees' wish to pull the ladder up after they ascend to the high ranks, but that assimilation is the name of the game for the women to 'survive' in a male-dominated context. The 'queen bee' metaphor describes the phenomenon in which some women assimilate into the masculine culture that dominates top management in big corporations, thereby legitimizing gender inequality (Derks et al. 2016). However, there is little evidence on whether women top managers actually act as 'queen bees'. It may be that the relatively few women who pursue careers in business life differ from women in general more than they do from men in their sector (Adams \& Funk 2012). According to Kanter (1977), the more gender balance in a top-management group, the more likely it is that women in that group will be viewed as individuals and not as 'symbols' or 'tokens'.

Thus, the second question in our analysis is about whether female top managers are more supportive of gender-equality initiatives than their male colleagues and about whether their support varies among different types of initiatives. We then proceed with analyzing if female top managers diverge less from their male counterparts in moregender-balanced than less-gender-balanced management groups, and whether support for gender-equality measures differ based on whether a company is part of CBQ regulations, that is, have $\mathrm{CBQ}$ regulations resulted in top managers being more supportive of such measures?

\section{Data and analytical method}

To explore our research questions, we used an e-mail based survey on top management, recruitment, and gender balance among top executives, conducted among top managers in the 200 biggest companies in Norway in 2014. The companies were picked from the 
DN500 list, which contains the 500 largest companies in Norway by revenue. The 200 biggest companies include PLCs (stock-listed companies), publicly owned companies, and private limited companies. The first two are subject to CBQ regulation, and the third is not. The survey was undertaken by the Institute for Social Research in Oslo and administered through the online survey company Questback. The questionnaire was sent to all managers in the top executive ranks, including both CEOs, managers in line positions, and managers in staff positions. Their e-mails were collected from the companies' websites or by direct contact with the companies. However, in some cases, the e-mail addresses did not work, which probably reflects the large turnover in some top management groups. Moreover, some companies were unwilling to provide us with the top managers' contact information and offered us to send an inquiry via a contact person instead. There were also some companies that picked only one manager to participate in the survey. A total of 404 top managers responded to the questionnaire, which amounts to $31 \%$ of those who actually received the survey. The response rate was somewhat higher for women than for men $(45 \%$ vs $28 \%)$. Thus, men are somewhat underrepresented in the net sample compared with the gross sample, which is also the case for top leaders in the biggest companies (by revenue), including companies with oil-related activities, and managers in companies that do not fall under the gender quota law. However, the net sample includes both men and women top managers from a variety of industries and company types (both companies that are subject to CBQ regulation and companies that are not), thereby providing a unique source for capturing top managers' experiences, practices, and opinions in Norway. A total of 173 companies were represented in the net sample. ${ }^{2}$ For further information about the survey design, sample, data-collection procedure, and response rate, see Halrynjo and Kitterød (2015).

The survey captured top managers' views on several topics about women and top management, as well as gender quotas for boards, management groups, etc., and also some information about their family situation, educational background, the composition of the top leader group, etc. We gauged participants' support for different measures to promote gender balance in top positions by asking them to what extent they believed in the importance of each item on a list of 12 measures. Participants were presented with the following possible conditions to achieve better gender balance in executive management:

(1) Leadership programs for women (Female Future, Futura, etc.)

(2) Internal mentor arrangements/leadership programs

(3) Requirements for reports and visibility of gender balance at the executive level

(4) Active recruitment policies for middle management

(5) Active recruitment policies for the executive level

(6) Preferential rights for female applicants when faced with applicants of equal competence

(7) Gender quotas for boards

(8) Raise women's awareness of career building

(9) More equal distribution of parental leave between mothers and fathers

(10) More equal distribution of children/family responsibilities between mothers and fathers

(11) Better opportunities for career comebacks after the "toddler phase"

(12) Increased education levels among women 
The last four measures (I, J, K, and L) refer to more general gender-equality policies than to measures at the company level and are, therefore, not included in our analyses in the present paper.

Participants were asked to assess the importance of each measure on a scale from one (very unimportant) to five (very important). In the analyses in the present paper, we recoded the variables from minus 2 to 2 , so that negative values reflect that a measure is considered unimportant, and positive values reflect that a measure is considered important. Observations with missing values (varying from three to seven for the nine statements that we looked at) are coded as 0 .

As for respondents, we included top managers from private limited companies (not subject to gender-quota laws), top managers from PLCs (stock-listed companies/subject to gender-quota laws), and top managers from state- and municipality-owned companies (subject to gender-quota laws) in the analyses. We excluded a few managers from companies without gender-quota mandates, especially various types of foundations. We ended up with 381 observations in the analyses, 107 women and 274 men.

In the empirical analysis, we started by investigating which measures are most and least supported by women and men top managers, then we investigated more closely the extent to which there are gender differences in top managers' support of various types of measures to promote gender balance in top management groups. To summarize the data, we constructed two indices, one on measures that approach managers' behavior, such as management training and recruitment, and one on measures that constrain managers' discretion to discriminate, such as different types of control systems. In addition, we included two single statements that do not fit into any of the two indices. We employed multivariate analyses [ordinary least square regression (OLS) and logistic regression] to control for relevant differences between female and male top leaders. The multivariate analyses also allowed us to explore whether female managers diverge less from their male counterparts in more-gender-balanced than in less-gender-balanced management groups, and whether managers at companies subject to CBQs are more supportive of gender-equality measures than managers in companies not subject to CBQs.

\section{Results}

\section{Most support for active recruitment measures}

First, we examine women and men top managers' opinions by looking at the average scores for the eight different measures to achieve better gender balance in top management (those denoted A-H in the section above), as well as the proportion with the two highest scores ( 1 or 2 ), meaning whether they regard the tool as rather or very important (Table 1). Most of these measures refer to tools implemented at the company level, but one of them (the one denoted A) stands out in that it refers to more general leadership programs, for example, programs arranged by the Confederation of Norwegian Enterprises, and not at the company level. However, all the measures presented in the survey have been widely discussed in debates on gender equality in business life in Norway and are well known by most top managers. We sorted the eight measures according to their average scores, with those with the highest scores at the top based on the women top 
Table I Average scores on various conditions to achieve better gender balance in executive management, and the percentage who believe that various conditions are rather or very important (scores I and 2) among women and men ( $N=108 / 278)$

\begin{tabular}{|c|c|c|c|c|}
\hline & \multicolumn{2}{|c|}{$\begin{array}{l}\text { Average score } \\
(-2 \text { to } 2)\end{array}$} & \multicolumn{2}{|c|}{$\begin{array}{c}\text { Rather/very } \\
\text { important } \\
\text { percent }\end{array}$} \\
\hline & Women & Men & Women & Men \\
\hline Active recruitment policies for middle management (D)a & $1.31(1)$ & $1.01(1)$ & 84 & 80 \\
\hline Active recruitment policies for the executive level (E) & $1.30(2)$ & $0.87(3)$ & 85 & 72 \\
\hline Raise women's awareness of career building $(H)$ & $1.17(3)$ & $0.90(2)$ & 84 & 73 \\
\hline Internal mentor arrangements (B) & $0.94(4)$ & $0.68(4)$ & 71 & 67 \\
\hline Reports and monitoring of gender balance (C) & $0.51(5)$ & $-0.61(7)$ & 55 & 34 \\
\hline Gender quotas for corporate boards $(\mathrm{G})$ & $0.13(6)$ & $-0.42(6)$ & 44 & 25 \\
\hline Leadership programs for women $(\mathrm{A})$ & $0.04(7)$ & $0.04(5)$ & 33 & 42 \\
\hline Preferential treatment of women $(F)$ & $-0.23(8)$ & $-0.7 \mid(8)$ & 23 & 17 \\
\hline
\end{tabular}

a The letters in parenthesis refer to the letters indicating the order in which the questions were asked. The full wording of each question is shown in the section on data and analytical method.

managers' answers. To ease the comparison of women's and men's rankings, we have marked the order in parenthesis.

The measure that received the most support is active recruitment policies for middle management. Eighty-four percent of women and $80 \%$ of men top managers believe this to be either a rather or very important measure. ${ }^{3}$ A significant majority of both female and male top managers also support active recruitment policies for the executive level. However, while women support such measures almost to the same extent as active recruitment policies for middle management, men seem to believe somewhat less in recruitment policies for the executive level than for middle management. Measures such as raising women's awareness of career building and internal mentor arrangements or leadership development programs also received strong support from both female and male top managers. However, leadership programs for women received more modest support, with only $33 \%$ of women and $42 \%$ of men believing that this is an important measure, a significant finding given that this statement refers to more general leadership programs, and not to programs arranged at the company level. Regulations such as preferential treatment for women also received modest support from top managers of both genders, and the same is true for reports and monitoring of gender balance and gender quotas for corporate boards, with only $25 \%$ of male top managers believing that gender quotas have any importance at all. ${ }^{4}$ Although women are somewhat more positive, only $44 \%$ believe gender quotas are either rather or very important.

Generally, top managers' support of gender-equality measures is strong, with a clear tendency for women and men top managers to support the same measures. They differ only slightly in the rankings for different tools. Both women and men seem to believe more in active recruitment policies and internal mentor arrangements than in more regulatory measures, which actually fit well with the finding by Dobbin et al. (2015) that measures and reforms that engage managers appeal more than regulatory measures that are imposed on managers and constrain their discretion. 
However, the bivariate analyses in Table 1 indicate that women top managers believe more in several of the tools for achieving gender equality in top management than men managers do, and that they are also somewhat less skeptical of regulatory measures than men. Still, men and women have the same average score when it comes to leadership programs for women. In fact, more men than women believe this is a rather or very important measure (42\% vs 33\%). To get further insight into the patterns behind the average scores reported in Table 1, we provided a detailed frequency distribution for each measure in Table 2. We noticed that even though both male and female managers tend to support the same measures, several measures are more often regarded as very important (score 2) by female leaders. Men are more prone than women to opt for score 1 , meaning they believe the measure in question is somewhat, but not very, important. Furthermore, the results suggest that there is no consistent pattern of male top managers being more indifferent (do not know/cannot decide) than women top managers. On some measures (such as preferential treatment of women), the percentage with a score of 0 is, in fact, somewhat higher for women than for men, while the reverse pattern is observed for other measures (such as active recruitment for middle management). However, some measures are looked upon as very unimportant by a large portion of men top managers, while women's views are

Table 2 Frequencies for scores on various conditions to achieve better gender balance in executive management $(-2$ = very unimportant, 2 = very important) as a percentage

\begin{tabular}{|c|c|c|c|c|c|c|c|c|c|c|c|c|}
\hline & \multicolumn{6}{|c|}{ Women } & \multicolumn{6}{|c|}{ Men } \\
\hline & -2 & -1 & 0 & $\mathbf{I}$ & 2 & Total & -2 & -1 & 0 & $\mathbf{I}$ & 2 & Total \\
\hline $\begin{array}{l}\text { Active recruitment } \\
\text { policies for middle } \\
\text { management }(D)^{a}\end{array}$ & I & I & 14 & 34 & 50 & 100 & 2 & 1 & 17 & 54 & 26 & 100 \\
\hline $\begin{array}{l}\text { Active recruitment } \\
\text { policies for the executive } \\
\text { level (E) }\end{array}$ & 1 & 0 & 14 & 39 & 46 & 100 & 3 & 3 & 23 & 50 & 22 & 100 \\
\hline $\begin{array}{l}\text { Raise women's awareness } \\
\text { of career building }(H)\end{array}$ & 2 & 3 & 11 & 45 & 39 & 100 & I & 5 & 21 & 47 & 25 & 100 \\
\hline $\begin{array}{l}\text { Internal mentor } \\
\text { arrangements/leadership } \\
\text { programs (B) }\end{array}$ & 0 & 3 & 26 & 46 & 25 & 100 & 3 & 6 & 23 & 53 & 14 & 100 \\
\hline $\begin{array}{l}\text { Reports and monitoring } \\
\text { of gender balance }(C)\end{array}$ & 6 & 14 & 26 & 33 & 21 & 100 & 12 & 20 & 34 & 30 & 4 & 100 \\
\hline $\begin{array}{l}\text { Gender quotas for } \\
\text { corporate boards }(G)\end{array}$ & 12 & 18 & 27 & 32 & 11 & 100 & 24 & 24 & 26 & 20 & 5 & 100 \\
\hline $\begin{array}{l}\text { Leadership programs for } \\
\text { women }(A)\end{array}$ & 6 & 26 & 34 & 24 & 9 & 100 & 13 & 19 & 27 & 37 & 5 & 100 \\
\hline $\begin{array}{l}\text { Preferential treatment } \\
\text { of women }(F)\end{array}$ & 11 & 30 & 36 & 18 & 6 & 100 & 29 & 31 & 24 & 15 & I & 100 \\
\hline
\end{tabular}

Women and men $(\mathrm{N}=108 / 278)$.

a The letters in parenthesis refer to the letters indicating the order in which the questions were asked. The full wording of each question is shown in the section on data and analytical method. 
more moderate (gender quotas for corporate boards and preferential treatment for women). For instance, $29 \%$ of men and $11 \%$ of women top managers believe that preferential treatment of women is very unimportant.

\section{Considerable gender differences across measures}

Our results so far suggest that both women and men top managers believe more in recruitment and training measures than regulatory measures to promote gender balance in top management groups, and that women are more supportive than men of the first type of tools and somewhat less opposed to the latter. To further investigate gender differences in support for different types of measures, we ran multivariate analyses with controls for relevant factors, such as for instance the managers' position in the top leader group and their field of education. We also explored whether gender differences vary with the gender composition of the top management group and whether top managers in companies with and without CBQs differ in their support for various types of tools to promote gender equality in top positions.

To summarize measures, we constructed two additive indices, one called 'Active recruitment' and another called 'Regulatory measures'. The first one comprises the three tools that approach managers' behavior, such as active recruitment policies for middle management, active recruitment policies for the executive level, and internal mentor arrangement/leadership programs. The second one comprises regulatory initiatives, such as requirements for reports and visibility of gender balance at the executive level, preferential treatment of women, and gender quotas for boards. ${ }^{5,6}$ Because the two remaining statements, 'Leadership programs for women' and 'Raise women's awareness of career building', did not, neither theoretically nor empirically, fit into any of the two indices, we included them as individual statements in the analyses.

Like the single statements, the indices range from -2 to 2 . The average scores are presented in Table 3 for the whole sample and separately for women and men. ${ }^{7}$ In accordance with the results provided in Table 1 , the active-recruitment dimension receives much support from both women and men, while regulatory measures receive less support. For women, the average score on the active recruitment dimension is 1.17, while the score on the regulatory measures dimension is 0.13 . For men, the corresponding averages are 0.86 and -0.40 , respectively. Thus, women support the first type of measures to a greater extent than men and are less negative toward the second type of measures. The two indices as well as two single statements ( $\mathrm{A}$ and $\mathrm{H}$ ) constitute our dependent variables in the multivariate analyses. Because they are all continuous variables, we use OLS.

In the multivariate analyses, the variables respondents' gender, gender composition of the management group, and company type (subject to CBQs or not) comprise our independent variables. In addition, we include controls such as respondents' age, age of youngest child (including no children), respondents' position in the management group, and respondents' field of education. Because more leaders from the same company participated in the survey, we controlled for this dependency by using an estimation procedure that yields robust standard errors. When interpreting the results, it is important to remember that the analyses are based on a small sample, which tends to yield imprecise estimates and makes attaining statistical significance difficult. 
Table 3 Descriptive statistics on dependent and independent variables in the multivariate analyses, averages, and percentages

\begin{tabular}{|c|c|c|c|}
\hline & All & Women & Men \\
\hline \multicolumn{4}{|l|}{ Dependent variables, average scores } \\
\hline \multicolumn{4}{|l|}{$\begin{array}{l}\text { Scales/statements on conditions to further gender } \\
\text { balance in executive management (-2 = very unim- } \\
\text { portant, } 2 \text { = very important) }\end{array}$} \\
\hline $\begin{array}{l}\text { Active recruitment (recruitment for middle and top management and } \\
\text { internal mentors - statements } B, D, E^{\text {a }} \text { ) }\end{array}$ & 0.95 & 1.17 & 0.86 \\
\hline $\begin{array}{l}\text { Regulatory measures (reporting, preferential treatment, and gender } \\
\text { quotas for boards - statements C, F, G) }\end{array}$ & -0.25 & 0.13 & -0.40 \\
\hline Raise women's awareness of career building (statement $\mathrm{H}$ ) & 0.97 & 1.16 & 0.90 \\
\hline Leadership programs for women (statement A) & 0.03 & 0.02 & 0.04 \\
\hline \multicolumn{4}{|l|}{ Independent variables, percentages } \\
\hline \multicolumn{4}{|l|}{ Respondent's gender } \\
\hline Man & 72 & & \\
\hline Woman & 28 & & \\
\hline \multicolumn{4}{|l|}{ Gender composition of the management group } \\
\hline Only men $(9|-| 00 \%)$ & 28 & 14 & 33 \\
\hline Most men (6I-90\%) & 47 & 46 & 47 \\
\hline Gender-balanced ( $\leq 60 \%$ men) & 25 & 40 & 20 \\
\hline \multicolumn{4}{|l|}{ Company type } \\
\hline Private-limited & 44 & 38 & 46 \\
\hline Stock-listed (quotas) & 27 & 25 & 27 \\
\hline Publicly owned company (quotas) & 30 & 36 & 27 \\
\hline \multicolumn{4}{|l|}{ Respondent's age (years) } \\
\hline $28-44$ & 19 & 31 & 15 \\
\hline $45-54$ & 51 & 51 & 50 \\
\hline $55-67$ & 30 & 18 & 35 \\
\hline \multicolumn{4}{|l|}{ Children (years) } \\
\hline $0-9$ & 20 & 24 & 19 \\
\hline $10-14$ & 18 & 18 & 18 \\
\hline $15-19$ & 23 & 22 & 24 \\
\hline $20+$ & 33 & 22 & 37 \\
\hline No children & 6 & 13 & 3 \\
\hline \multicolumn{4}{|l|}{ Position in executive management } \\
\hline CEO/deputy CEO & 37 & 22 & 42 \\
\hline Staff & 30 & 50 & 22 \\
\hline Line role, other & 34 & 28 & 36 \\
\hline \multicolumn{4}{|l|}{ Field of education } \\
\hline Technical/scientific & 31 & 16 & 37 \\
\hline Finance/business & 51 & 54 & 50 \\
\hline Law/social sciences/humanities & 14 & 22 & 12 \\
\hline Other/unknown & 3 & 8 & 1 \\
\hline Number of observations & 381 & 107 & 274 \\
\hline
\end{tabular}

aThe letters in parenthesis refer to the letters indicating the order in which the questions were asked. The full wording of each question is shown in the section on data and analytical method. 
Frequency distributions for the independent variables are presented in Table 3. Female and male top managers comprise $28 \%$ and $72 \%$ of the analysis sample, respectively. ${ }^{8}$ Apart from company type, there are considerable gender differences in the distribution of all independent variables. The female leaders generally belong to more gender-balanced management groups than men, are somewhat younger, seldom have adult children, more often have no children, more often have a staff position in the management group, less often have other line positions or a CEO position, and are more often educated in the fields of law, social sciences, and humanities, and less often in technical or scientific fields.

In Table 4, we present results from OLS regressions with the two indices 'Active recruitment' and 'Regulatory measures', as well as the two single measures 'Raise women's awareness of career building' and 'Leadership programs for women' as the dependent variables. In line with the bivariate analysis presented above, the regression results reveal that female top managers believe more in active recruitment measures to further gender balance in top management groups than men, and also are less skeptical of regulatory measures. The gender differences are considerable and statistically significant (at the 0.01 level) even after controlling for the gender composition of the management group, company type, the top managers' age, family situation, management position, and field of education. Women also clearly believe more in raising women's awareness of career building than men do (statistically significant at the 0.05 level), and this is true even after controlling for a number of relevant factors.

Importantly, however, in line with the average scores in Table 1, the OLS regression analysis reveals that women and men do not differ on the extent to which they support more general leadership programs for women. Still, as shown in Table 1, more men than women managers believe this type of measure is either very or rather important $(42 \%$ vs $33 \%)$. To investigate whether this gender difference applies in a multivariate framework as well, we constructed a dummy variable in which scores 1 and 2 (rather or very important) equal 1 and lower scores $(-2,-1$, and 0$)$ equal 0 . Because our dependent variable is a dummy variable, we used logistic regression in the multivariate analysis. We included the same set of independent variables as in the OLS analyses. The results are reported as odds ratios (see Table 5), which means that the reference group for each variable is set to 1 , and that coefficients above 1 indicate a positive association, whereas coefficients below 1 indicate a negative association. We note that the gender difference in support for general leadership programs as a tool to further gender balance in top management groups applies also in a multivariate framework. The coefficient is statistically significant at the $0.10 \%$ level. Hence, men seem to believe in such measures more than women, and the gender difference is hardly reduced when relevant factors, such as the gender composition of the management group, company type, the respondent's age, family situation, management position, and field of education are accounted for. ${ }^{9}$

Regarding our second research question, we can conclude that even women who have managed to break the glass ceiling and become part of a top management group are, on average, more supportive of most gender-equality measures than their male counterparts, and that this holds also when a number of relevant variables have been controlled for. We note, however, that women do not, on average, differ from men in their support for more general leadership programs for women, and that fewer women than men believe this is an important condition to enhance gender balance in executive management in Norway. 


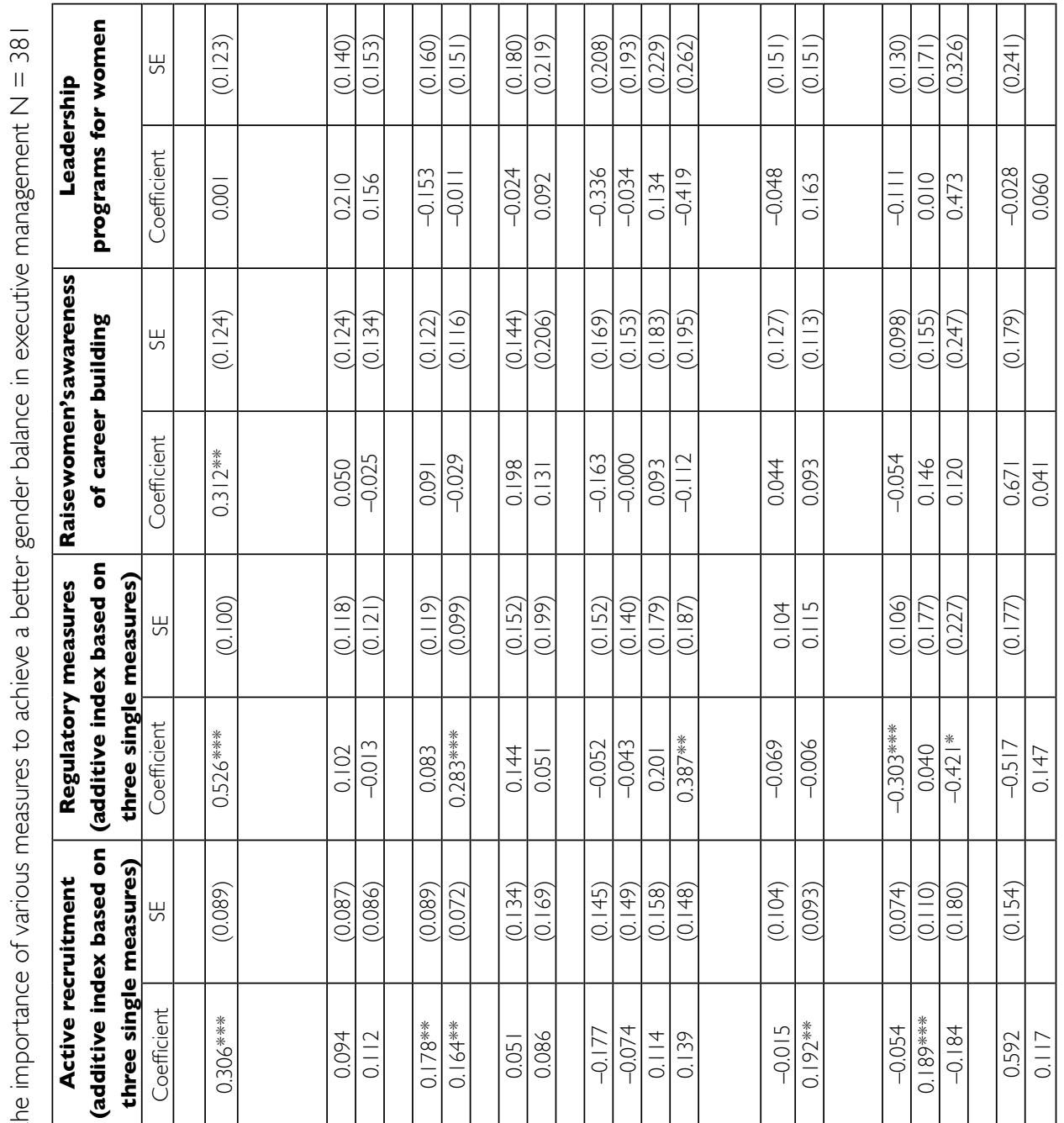
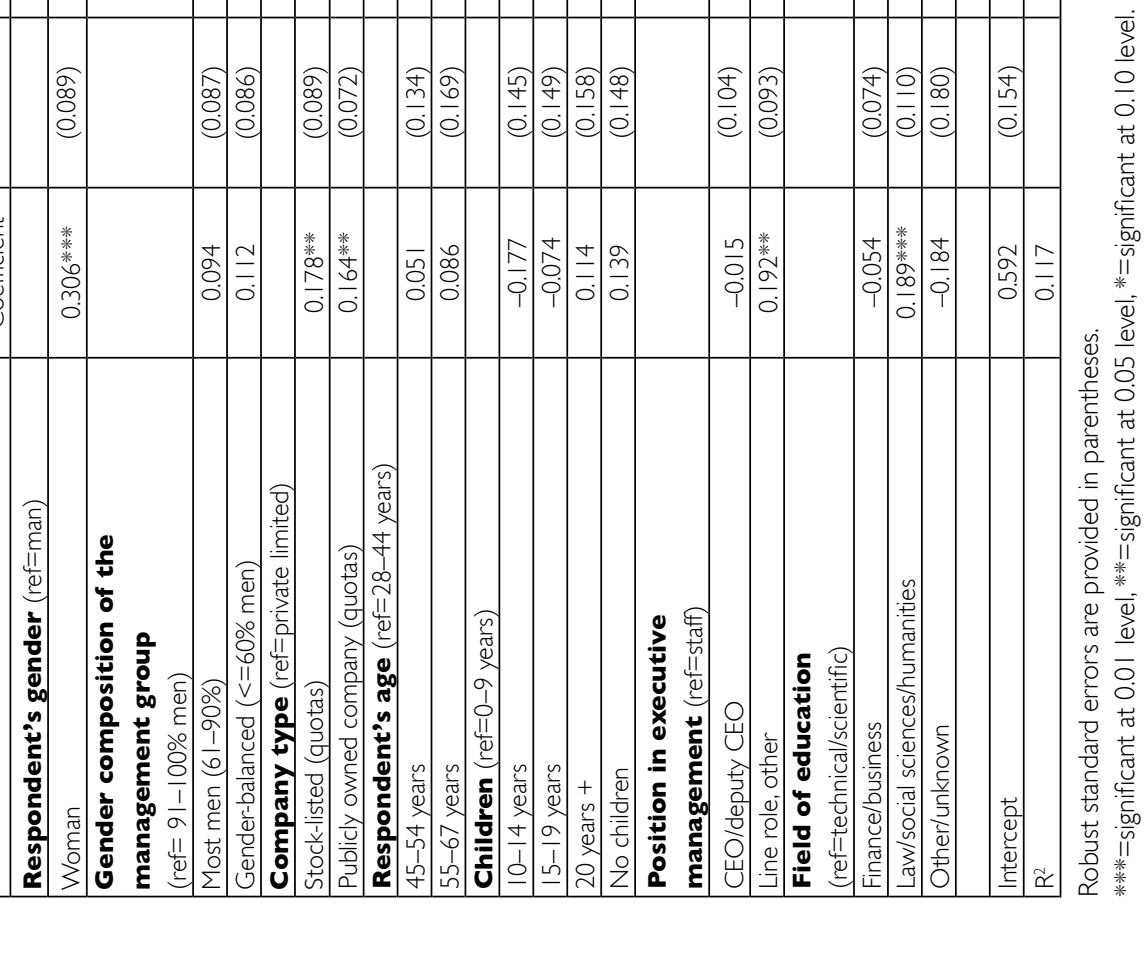
Table 5 Results from logistic regression analysis of the importance of leadership programs for women as a measure to achieve a better gender balance in executive management ( $\mathrm{I}=$ rather/very important, $0=$ not important/indifferent $)$

\begin{tabular}{|c|c|c|}
\hline & Odds ratio & $\begin{array}{l}\text { 95\% confidence } \\
\text { interval }\end{array}$ \\
\hline \multicolumn{3}{|c|}{ Respondent's gender (ref=man) } \\
\hline Woman & $0.656 *$ & $0.412-1.047$ \\
\hline \multicolumn{3}{|c|}{$\begin{array}{l}\text { Gender composition of the management } \\
\text { group (ref }=91-100 \% \text { men })\end{array}$} \\
\hline Most men (61-90\%) & $2.013^{*} * * *$ & $1.191-3.402$ \\
\hline Gender-balanced (<=60\% men) & 1.243 & $0.662-3.334$ \\
\hline \multicolumn{3}{|c|}{ Company type (ref=private limited) } \\
\hline Stock-listed (quotas) & 0.725 & $0.418-1.255$ \\
\hline Publicly owned company (quotas) & 0.880 & $0.505-1.53 \mid$ \\
\hline \multicolumn{3}{|c|}{ Respondent's age (ref=28-44 years) } \\
\hline $45-54$ years & 0.969 & $0.500-1.877$ \\
\hline $55-67$ years & 1.040 & $0.448-2.418$ \\
\hline \multicolumn{3}{|l|}{ Children $(r e f=0-9$ years $)$} \\
\hline 10-14 years & 0.751 & $0.336-1.676$ \\
\hline $15-19$ years & 1.112 & $0.537-2.302$ \\
\hline 20 years + & 1.369 & $0.592-3.168$ \\
\hline No children & 0.525 & $0.158-1.740$ \\
\hline \multicolumn{3}{|l|}{$\begin{array}{l}\text { Position in executive } \\
\text { management (ref=staff) }\end{array}$} \\
\hline CEO/deputy CEO & 0.808 & $0.448-1.449$ \\
\hline Line role, other & 1.191 & $0.686-2.07 \mid$ \\
\hline \multicolumn{3}{|c|}{ Field of education (ref=technical/scientific) } \\
\hline Finance/business & 0.822 & $0.522-1.295$ \\
\hline Law/social sciences/humanities & 0.834 & $0.487-1.642$ \\
\hline Other/unknown & 2.323 & $0.635-8.500$ \\
\hline Intercept & 0.597 & $0.264-1.351$ \\
\hline
\end{tabular}

$N=381$. (95\% confidence interval in parentheses).

***=significant at 0.0 I level, * =significant at 0.10 level.

Apart from the gender difference, the multivariate analyses presented in Table 4 reveal few systematic dividing lines in top managers' views on measures to achieve gender balance among top managers. Therefore, it seems safe to conclude that gender constitutes the most important and unambiguous dividing line when it comes to top managers' support of different tools to promote gender equality in top management 
groups in Norway. However, as demonstrated in the bivariate analyses in Table 2, there is no clear pattern of women supporting and men being indifferent or skeptical toward all types of measures. Vast majorities of both female and male top managers are in favor of active recruitment measures, although men are slightly less positive than women. Moreover, most female and male top leaders are either indifferent or unsupportive of regulatory measures, although women are somewhat less skeptical than men.

Turning to our third research question, whether female managers diverge less from their male counterparts in more-gender-balanced than less-gender-balanced management groups, we re-ran the multivariate analyses with an interaction term between the respondent's gender and the gender composition of the management group (results are available from the authors by request). As demonstrated in Table 4, contrary to our expectations, top managers in gender-balanced top management groups do not differ from those in male-dominated groups in their support of various types of measures to advance gender balance in top management. Also, the analyses with interactions between the respondent's gender and the gender balance in his or her management group revealed no statistically significant interaction effects. However, the small size of our sample only allows for a rather crude categorization of the gender balance in the management group, and it cannot be ruled out that a different categorization would have produced other results. Therefore, on the basis of our data, we cannot draw a firm conclusion on the relationship between the gender balance in management and individual managers' support for gender-equality measures, although the noninteraction between the top managers' gender and the gender composition in the management group is a consistent finding across measures.

\section{More support for some measures in companies subject to CBQs}

As for our fourth research question, whether support for gender-equality measures differs based on whether a company is subject to CBQs or not, the results from the multivariate analyses (see Table 4) reveal that managers at companies subject to CBQ laws are more in favor of active-recruitment measures to promote gender balance in top management than managers in companies that are not subject to CBQs (private limited companies). The difference holds for leaders at stock-listed companies, as well as for those at publicly owned companies, and it is important to note that it applies even after controlling for a lot of relevant factors, including the manager's gender, position in the management group, field of education, and the gender balance in the management group. We further note that managers at publicly owned companies are more supportive of/less skeptical of regulatory measures than managers at private-limited companies, whereas managers at stock-listed companies do not differ from those at private-listed companies in this respect. Tools such as 'Raising women's awareness of career building' and 'Leadership programs for women' are supported to the same extent by leaders in companies subject to CBQ laws and leaders in companies that are not subject to CBQ laws.

\section{Discussion and concluding remarks}

In the Introduction to this article, we first addressed a question about what measures to further gender balance in top management are the most and least supported by top 
managers at Norwegian companies. We found that active recruitment policies receive the strongest support, and quota and preferential-treatment policies receive the least support. Second, we examined gender differences in support patterns and found clear similarities between men and women in the ranking of measures, although women are generally stronger in their support of all measures, except for leadership programs for women, which men in the executive ranks support more than fellow women top managers. These results also apply in a multivariate framework in which relevant factors are accounted for. We believe this is an important finding because it implies that women top managers' stronger support for most gender-equality measures to promote gender equality applies irrespective of their position in the management group, field of education, whether the company is subject to quota regulation for boards or not, the gender balance in the executive management group and family factors. We then examined whether gender differences are less pronounced in gender-balanced management groups and found no differences related to the gender composition of top management ranks. Neither did we find any consistent pattern tied to company type across different genderequality measures distinguishing between CBQ and non-CBQ companies. However, and interestingly, top managers at companies subject to CBQs are significantly more supportive of active recruitment policies than top managers at private-limited companies. There are no differences in relation to measures geared toward 'training and encouraging women', but top managers at publicly owned companies are more supportive of, or at least less-skeptical of, regulatory measures than top managers at public-limited and private-limited companies.

Dobbin et al. (2015) argue that equality and diversity are best pursued by implementing measures that motivate and engage top managers. Our analysis indicates overwhelming support for various gender-equality measures, with the main exceptions being only modest support for quota measures and preferential treatment of women. Hence, to some extent, we would argue that this broadly shared enthusiasm makes it rather difficult to sort out which measures engage top managers, as well as which are most effective at pushing for change. However, support for active recruitment policies at the middle-management level among both female and male leaders appears strong and solid, which we believe is interesting in view of the fact that these fall within the type of measures that according to Dobbin et al. (2015) are the most effective in bringing about change in equality and diversity in companies in the US context.

Another question is what it actually means when Dobbin et al. (2015) assert that measures that engage and motivate top managers are the most effective. Does it mean that it does not really matter what kinds of measures are implemented, that is, is it simply top managers' engagement and commitment that matter most? If the type of measure does matter, it is worth noting that male top managers are more supportive of leadership-development programs for women than their women colleagues. Typically, these are programs outside the company, arranged by, for instance, an employer organization. Why are men more in favor of this than women? Most likely, women are less enthusiastic about 'women programs' on the basis of their own experiences, illustrating that those who have managed to break through the 'glass-ceiling' find the gender-balance problem to be more about organizational matters than 'fixing other women'. Our study shows that gender has an independent and significant effect on support for genderequality measures. Although some tools elicit strong support from leaders of both genders, women more often than men believe these tools are very important, rather than 
somewhat important. Hence, we do not find support for the 'queen bee' mechanism. Instead, the analysis points at women in top positions in business life as potential agents for change. So, why have we not been witnessing greater gender-equality change at the top? One reason may be that women top managers are relatively few and dispersed to many companies, with relatively little influence wherever they work. In addition, these women are typically placed in staff, not line positions. Hence, their power to assert their will may be weaker than that of CEOs and line managers. On the other hand, women are more often HR executives, which are strategically important positions when it comes to introducing and shepherding internal gender-equality policies.

Furthermore, it might be that although women in top management positions are particularly strong supporters of gender-equality measures, they still may act as 'queen bees' in practice. As long as promotion of gender balance in top management is not a high priority in the top management ranks - and maybe not even among women top managers (although they are very much in favor of such policies) - there will be concerns about gender-equality backsliding amid other 'bigger' strategic considerations in the daily management of the company.

As to the question addressed in the introduction to this study, of whether top managers' ranking of gender-equality measures can contribute to explaining the lack of 'ripple effects' from corporate-board quotas, we may not be able to answer it in full. But we may conclude that the lack of enthusiasm for quota policies as a tool to further gender balance in top management positions probably has not contributed to any 'ripple effects', nor to motivating top managers to initiate internal gender-equality policies to promote gender balance in top management. Top managers' modest enthusiasm for quota policies indicate that CBQs are not well-suited for spurring enthusiasm to promote gender balance in top management, although they have been quite effective in promoting gender balance on corporate boards (Teigen 2015) and are also widely supported by top managers as a tool to further gender balance in boards (Kitterød et al. 2015).

Nevertheless, our findings suggest that top managers are the most engaged and motivated by active recruitment policies, with particular attention paid to middle-management ranks. This fits well with argument by Dobbin et al. (2015) for policies that takes top managers' discretion into account. Obviously, some companies in Norway have developed active recruitment policies to promote gender balance. Still, we know that many have not. If more companies develop such policies from the inside, there may be prospects to see more change happen. Moreover, our study indicates that the lack of ripple effects from gender-balanced corporate boards toward improving gender balance in top management ranks may be connected to gender quotas being the least-favored measures by top managers in the business sector, although we have no findings indicating that these measures have been counterproductive. Combining different types of measures may in fact prove to be what are the most effective.

In spite of the small sample used in the analyses in the present paper and the underand overrepresentation of certain groups of top managers, we believe that our findings contribute to the debate about possible remedies to further gender balance in top leader groups in large companies in Norway as well as other countries, and we hope the questions addressed in the paper will be further researched in future studies with larger and completely representative samples. 


\section{Acknowledgments}

This research was supported by the Research Council of Norway through the project Gender Segregation in the Labour Market: Comparative Perspectives and Welfare State Changes (Grant \#236770), and by CORE - Centre for Research on Gender Equality at Institute for Social Research in Oslo.

\section{References}

Adams, R. B. \& Funk, P. (2012). Beyond the glass ceiling: does gender matter? Management Science 58: 219-235. doi: https://doi.org/10.1287/mnsc.1110.1452.

Ambrose, M. L. \& Schminke, M. (2015). What drives trickle-down effects? A test of multiple mediation processes, Academy of Management Journal 58: 1848-1868. doi: https://doi. org/10.5465/amj.2013.0670

Brandth, B. \& Kvande, E. (Eds.) (2013). Fedrekvoten og den farsvennlige velferdsstaten. [The Fathers' Quota and the Father-Friendly Welfare State], Oslo: Universitetsforlaget.

Castilla, E. J. (2011). Bringing managers back in: managerial influences on workplace inequality, American Sociological Review 76: 667-694. doi: https://doi. org $/ 10.1177 / 0003122411420814$

Datta Gupta, N., Smith, N. \& Verner, M. (2008). The impact of Nordic countries' familyfriendly policies on employment, wages, and children, Review of Economics of the Household 6: 65-89. doi: https://doi.org/10.1007/s11150-007-9023-0

Davis, S. N. \& Greenstein, T. N. (2009). Gender ideology: components, predictors, and consequences, Annual Review of Sociology 35(1): 87-105. doi:10.1146/annurev-soc070308-115920

Derks, B., Van Laar, C. \& Ellemers, N. (2016). The queen bee phenomenon: why women leaders distance themselves from junior women, The Leadership Quarterly 27: 456-469. doi: http://dx.doi.org/10.1016/j.leaqua.2015.12.007

Dobbin, F., Schrage, D. \& Kalev, A. (2015). Rage against the iron cage: the varied effects of bureaucratic personnel reforms on diversity, American Sociological Review 80: 1014-1044. doi: https://doi.org/10.1177/0003122415596416

Ellingsæter, A. L., Kitterød, R. H. \& Lyngstad, J. (2017). Universalising childcare, changing mothers' attitudes: policy feedback in Norway, Journal of Social Policy 46: 149-173. doi: https://doi.org/10.1017/S0047279416000349

Ellingsæter, A. L. \& Leira, A. (2006). Epilogue: Scandinavian policies of parenthood - a success story? 265-277. In A. L. Ellingsæter \& A. Leira (Eds.), Politicising Parenthood in Scandinavia: Gender relations in welfare states, Bristol, UK: Polity Press.

Engeli, I. \& Mazur, A. (2018). Taking implementation seriously in assessing success: the politics of gender equality policy, European Journal of Politics and Gender 1: 111-129 (19). https://doi.org/10.1332/251510818X15282097548558

Hakim, C. (2011). Feminist myths and magic medicine: the flawed thinking behind calls for further equality legislation. Retrieved from London, UK: http://eprints.lse.ac.uk/36488/ (Accessed June 2018).

Halrynjo, S. \& Kitterød, R. H. (2015). Appendiks: Institutt for samfunnsforsknings undersøkelse Toppledelse, rekruttering og kjønnsbalanse 2014: Gjennomføring og svarprosent [Appendix: Institute for Social Research's survey on top management, recruitment, and gender balance 2014: Implementation and response rate]. In M. Teigen (Ed.), Virkninger av kjønnskvotering $i$ norsk noeringsliv [Effects of the Gender Quota Legislation in Norwegian Business Life], Oslo: Gyldendal Akademisk. 
Hellevik, T. \& Hellevik, O. (2012). Holdninger til likestilling [Attitudes Toward Gender Equality] 117-160. In T. Hansen \& B. Slagsvold (Eds.), Likestilling hjemme [Gender Equality in the Family]. Oslo: NOVA - Norsk institutt for forskning om oppvekst, velferd og aldring.

Huffman, M. L. (2013). Organizations, managers, and wage inequality, Sex Roles 68: 216222. doi: https://doi.org/10.1007/s11199-012-0240-5

Inglehart, R. \& Norris, P. (2003). Rising Tide, New York: Cambridge University Press.

Kanter, R. M. (1977). Men and Women of the Corporation, New York: Basic Books.

Kitterød, R. H., Teigen, M. \& Halrynjo, S. (2015). Flere kvinner på toppen? Holdninger til Likestilling blant toppledere [More women in top positions? Attitudes toward gender equality among top mangers]. 63-96. In Teigen, M. (Ed.). Virkninger av kjønnsbalanse $i$ norsk neringsliv [Effects of the Gender Quota Legislation in Norwegian Business Life], Oslo: Gyldendal Akademisk.

Knight, C. R. \& Brinton, M. C. (2017). One Egalitarianism or several? Two decades of gender-role attitude change in Europe, American Journal of Sociology 122: 1485-1532. doi: https://doi.org/10.1086/689814

Korpi, W. Ferrarini, T., \& Englund, S. (2013). Women's opportunities under different family policy constellations: gender, class, and inequality tradeoffs in western countries reexamined, Social Politics: International Studies in Gender, State \& Society 20: 1-40. doi: https://doi.org/10.1093/sp/jxs028

Kunze, A. \& Miller, A. R. (2017). Women helping women? Evidence from private-sector data on workplace hierarchies, Review of Economics and Statistics 99: 769-775. doi: https:// doi:10.1162/REST_a 00668

Lister, R. (2009). A Nordic nirvana? Gender, Citizenship, and social justice in the Nordic welfare states, Social Politics: International Studies in Gender, State \& Society 16: 242-278. doi: https://doi.org/10.1093/sp/jxp007

Mandel, H. \& Semyonov, M. (2006). A welfare state paradox: state interventions and women's employment opportunities in 22 countries, American Journal of Sociology 111: 1910-1949. doi: https://www.jstor.org/stable/10.1086/499912

Melby, K., Ravn, A.-B. \& Wetterberg, C. C. (Eds.). (2009). Gender Equality and Welfare Politics in Scandinavia. The Limits of Political Ambition? Bristol, UK: Policy Press (University of Bristol).

Niskanen, K. (ed.) (2011). Gender and Power in the Nordic Countries - With Focus on Politics and Business, Oslo: NIKK-publication 2011: 1. http://www.nikk.no/wp-content/ uploads/NIKKpub2011 broschyr K\%C3\%B8n-og-magt Gender-Power.pdf (Accessed June 2018)

Petersen, T. (2002). Likestilling i arbeidsmarkedet [Gender equality in the labor market]. Tidsskrift for samfunnsforskning, 43: 443-478.

Shalev, M. (2008). Class divisions among women, Politics \& Society 36: 421-444. doi: https://doi.org/10.1177/0032329208320570

Teigen, M. (2012). Gender Quotas in Corporate Boards - On the diffusion of a distinct national policy reform. 115-146. In F. Engelstad \& M. Teigen (Eds.), Firms, Boards and Gender Quotas: Comparative Perspectives. Comparative Social Research (Vol. 29). Bingley, UK: Emerald.

Teigen, M. (ed.) (2015). Virkninger av kjønnsbalanse i norsk næringsliv [Effects of the Gender Quota Legislation in Norwegian Business Life], Oslo: Gyldendal Akademisk.

Teigen, M. (2018). The "natural" prolongation of the Norwegian Gender Equality Policy Institution. 341-365. In E. Lépinard \& R. R. Marin (Eds.), Transforming Gender Citizenship: The Irresistible Rise of Gender Quotas in Europe, Cambridge, UK: Cambridge University Press. 
Teigen, M. \& Wängnerud, L. (2009). Tracing gender equality cultures: elite perceptions of gender equality in Norway and Sweden, Politics and Gender 5: 21-44. doi: https://doi. org/10.1017/S1743923X09000026

Teigen, M. \& Skjeie, H. 2017. The Nordic gender equality model. In Oddbjørn Knutsen (ed.), The Nordic Models in Political Science. Challenged but still viable? Oslo: Fagbokforlaget: $125-148$.

Terjesen, S., Sealy, R. \& Singh, V. (2009). Women directors at corporate boards: a review and research agenda, Corporate Governance: An International Review 17: 320-337. doi: https://doi.org/10.1111/j.1467-8683.2009.00742.

Wolbrecht, C. \& Campbell, D. E. (2007). Leading by example: female members of parliament as political role models, American Journal of Political Science 51: 921-939. doi: https:// doi.org/10.1111/j.1540-5907.2007.00289.x

\section{Notes}

1 'The Act Relating to Gender Equality', Ministry of Children and Equality, published April 20, 2007, https://www.regjeringen.no/en/dokumenter/the-act-relating-to-gender-equality-the-/id454568/ (Accessed May 2018).

2 In 64 companies, one of the top managers responded to the survey, in 43 companies two mangers responded, in 30 companies three managers responded, and in 36 companies at least four managers responded.

3 The average score is 1.31 and 1.01 among women and men top managers, respectively.

4 The average score for the assessment on the suitability of gender quotas for boards is 0.13 and minus 0.42 for women and men, respectively.

5 The scales were created by summarizing the scores on the relevant measures, and dividing the sum by the number of measures included.

6 Factor analyses support the theoretical assumptions that the two sets of statements actually do capture two underlying concepts. In a factor analyses of the three tools included in the active recruitment scale, the eigenvalue is 2.06 , and in an analysis of the three tools included in the regulatory measures scale, the eigenvalue is 1.90 . The scale-reliability coefficients are 0.76 and 0.71 , respectively. Separate analyses for each gender reveal scale-reliability coefficients of 0.73 and 0.66 for women for the two scales, respectively, and 0.75 and 0.70 for men.

7 A few observations with missing values on the variable capturing whether the respondents have children or not are excluded from the multivariate analysis. Therefore, the number of observations is slightly lower in Table 3 than in Tables 1 and 2 (381 vs 386).

8 Due to the higher response rate among women than men, women are somewhat overrepresented in the net sample compared to the gross sample in which they made up $18 \%$ (see Halrynjo \& Kitterød 2015).

9 A logistic regression analysis in which the top manager's gender constitutes the only independent variable produces an odds ratio of 0.662 . Results are available from the authors on request. 